\title{
THE LAWYER AND THE SCIENTIFIC COMMUNITY- PROCURING BASIC RESEARCH
}

\author{
LEROY KAHN*
}

The phenomenal growth of science and technology in the past generation and the expenditures of large sums of public funds for the corresponding development of new weapons systems have brought into sharp focus the necessity for and significance of basic research for defense purposes in addition to "hardware" development, Since the search for fundamental knowledge covers the entire spectrum of the scientific environment, it is an obvious conclusion that any governmental basic research program must, perforce, have the assistance of the entire scientific community. ${ }^{1}$

There has been a tremendous effort in the Department of Defense to enhance the in-house laboratory capability for basic research and the results have been startlingly effective. Nevertheless, the wide scope of scientific activities necessarily required in this age of orbital flights, space exploration, and the urgency for superiority in defensive weapons has resulted in joint research efforts between government scientists and their civilian colleagues. The basic research facilities of commercial organizations, universities, and non-profit institutions are utilized to the maximum extent possible, with the consequent procurement problems generated by the large expenditure of public funds.

Research and development procurement in the Department of Defense, by the very nature of the end product desired, must keep step with the dynamic flow of ideas, scientific approach, and future, as well as present, technological sources of research. The rapid evolution of technology, changing concepts in scientific approach, the urgencies of immediate situations based upon economic and political atmospheres, make it essential for those responsible for administering the basic research program to be in step with the ever present requirements and to mold the program for the future as well as the present. "Hardware" development is the practical application of the results of basic research and this paper shall limit itself to some of the problems generated in a defense-related basic research program.

Large expenditures of public funds require necessary safeguards to protect the

* B.S., LL.B., LL.M., New York University; Dr.Jur., University of Johannes Gutenberg, Mainz, Germany. Colonel, United States Air Force. Staff Judge Advocate, Fq., Office of Aerospace Research. Member of the New York and Virginia bars.

The views expressed herein are the author's and do not necessarily reflect the official views of any government agency.

3 The author is most familiar with basic research problems in the Air Force which are illustrative, to a large extent, of the problems presented to lawyers in other government agencies concerned with basic research. Consequently, this discussion will confine itself to the relationship of the lawyer with the scientific community engaged in defense related basic research, with particular emphasis on matters of concern to the Air Force. 
public interest. The public treasury is not a bottomless pit and, although it is mandatory to achieve the maximum effectiveness for every dollar expended, there is a certain intangible inherent in basic research procurement which is ofttimes difficult for the contracting officer, procurement specialist, and lawyer to comprehend. The end product of a procurement action in basic research is either an idea, a concept, an approach to other basic research in the same or similar areas, or a conclusion which is merely the beginning for the exploration of other ideas or concepts. The fact that the end product of a procurement action is not a tangible thing which can be seen, felt, packaged, or transported, is probably the most difficult concept for the non-scientist to comprehend. It necessarily follows that a proper understanding of the basic research program and its part in governmental activities is essential if the lawyer is to make any effective contribution to the mission of his agency. To the lawyer brought up and trained in the area of social sciences this becomes a task of some magnitude, particularly if he is foreign to the scientific environment.

Basic research is the search for fundamental knowledge in the entire spectrum of science. The magnitude of this effort staggers the imagination and affects every area of our society. The tangential problems resulting from the basic research effort in a complicated society bring the lawyer into the picture and he can make an important contribution to this effort, non-scientist though he may be. Since defenserelated basic research has such a significant effect upon the future of the United States, as well as upon the economic, social, and political mores of the entire community, it is of great import to understand the relationship between the lawyer and scientific community in that area. The government scientist who is rightfully concerned with his research is ofttimes prone to lose sight of the fact that the lawyer, foreign as his discipline may appear to be from the scientific discipline, is an integral part of the scientific community.

Governmental research, specifically basic research, is the result of the marriage between in-house laboratory efforts and a contract and grant program with nonprofit or industrial institutions. The many complex problems generated by either effort requires the support of the lawyer if only to get a project "dff the ground." Legal and administrative problems must be resolved prior to the commencement of research, and it is the responsibility of the lawyer to insure that any impediment is resolved to the end that the research can reach its desired fruition. It is indeed true that the government scientist has accepted the assistance of the lawyer and has recognized the need for his talents and knowledge of the intricacies of government procurement and administration. However, the welcoming support of the legal discipline on the part of the scientist is only one side of the coin. The problems facing the lawyer in a governmental scientific environment are not dissimilar to those presented to the attorney in the same posture outside of government, particularly in view of the interest the federal government has in all aspects of research. The effectiveness of the lawyer's contribution to any basic research effort, particularly in 
government, requires him to have a firm, comprehensive, and complete understanding of the significance of the effort and the manner in which apparently disparate programs are tied in with the ultimate goals. He must comprehend the necessity to obtain fundamental knowledge and characteristically have or obtain the same patience, tolerance, enthusiasm, and diligence possessed by the dedicated scientist.

The lawyer who finds himself professionally engaged in a scientific community must first of all find a common ground for understanding with his scientific colleague, if he is to function at all effectively. An understanding on the part of the scientist of the role of the lawyer in his research efforts is as important as the comprehension the lawyer must have of the scientist's approach to his ultimate goal if there is to be any basis for mutual understanding. Despite apparent differences in training, technique, and background, there is a common design inherent in the scientific and legal approach to the resolution of the end result. Both the scientist and the lawyer are concerned with fundamental truths; both have been trained in the technique of inductive thinking; both have been trained to filter the incompetent from the relevant, to examine and analyze each and every aspect of any problem prior to formulating definitive conclusions, and to formulate the ratio decidendi of the question presented as a stepping stone for generalizations in any given area.

The tremendous scope of governmental activity in basic research is of such proportions that the scientific community, both in and out of government, has been called upon to contribute its efforts. The in-house laboratory effort of government scientists has made, and will continue to make, considerable contributions to basic research, despite the problems generated by its very nature as a governmental operation. Although these problems are many and varied, tremendous strides have been made for insuring its success, in those areas susceptible to solution. Broad problem areas of recruitment and hiring of competent qualified scientists, with allied problems of grade structure, salary, promotion and career development, manpower space authorizations, funding problems, flexible procurement of necessary supplies and services, research management difficulties, and problems affecting retention of the military scientist, are some internal problem areas which are part and parcel of an in-house scientific effort. Even if all problem areas are eventually resolved, in-house capability must be reinforced by drawing upon the talents available in colleges, universities, non-profit organizations and industry if the research effort is to be at all effective and keep pace with the dynamics of science.

The pursuit of science is not of academic interest to a nation inextricably entwined in global problems, the exploration of space, and the struggle for survival in a highly technological age. In July Ig6r, the President requested the Director of the Budget to review the effectiveness of the use of contracts with private institutions and enterprises which accomplish scientific and technical work "essential to urgent public purposes." The Secretary of Defense, Chairman of the Atomic Energy Commission, Chairman of the Civil Service Administration, and Special Assistant to the President for Science and Technology were also requested to participate in 
the study. After a comprehensive inquiry, the results were forwarded to the President in April, rg62. ${ }^{2}$

An enterprise of major dimensions which commands a substantial portion of the nation's wealth requires the availability and utilization of the nation's best minds. The expanding interests of the federal government and the consequent concentration of wealth and energy upon scientific endeavors have assumed such proportion that approximately half of the basic research conducted in the United States is federally financed. Immediately subsequent to World War II the principal means of obtaining this large scale research effort, particularly defense related research, was by contract to industry, universities, and non-profit institutions. ${ }^{3}$ Since I947, with the passage of the Armed Services Procurement Act, ${ }^{4}$ defense research contracting has been part and parcel of the act and Armed Services Procurement Regulation to the dismay, at times, of the scientist who finds it difficult to compre.

${ }^{2}$ U.S. Bureau of the Budget, Report to the President on Government Contracting for Research and Development (the Bell Report), S. Doc. No. 94, 87th Cong., $2 \mathrm{~d}$ Sess. at vii-viii (1962). In part the report stated:

" $r$. Federally financed research and development work has been increasing at a phenomenal ratefrom \$roo million per year in the late 1930's to over \$ro billion per year at present, with the bulk of the increase coming since 1950 . Over 80 percent of such work is conducted today through non-Federal institutions rather than through direct Federal operations. The growth and size of this work, and the heavy reliance on non-Federal organizations to carry it out, have had a striking impact on the Nation's universities and its industries, and have given rise to the establishment of new kinds of professional and technical organizations. At present the system for conducting Federal research and devclopment work can best be described as a highly complex partnership among various kinds of public and private agencies, related in large part by contractual arrangements.

"While many improvements are needed in the conduct of research and development work, and in the contracting systems used, it is our fundamental conclusion that it is the national interest for the Government to continue to rely heavily on contracts with non-Federal institutions to accomplish scientific and technical work needed for public purposes. A partnership among public and private agencies is the best way in our society to enlist the Nation's resources and achieve the most rapid progress.

"2. The basic purposes to be served by Federal research and development programs are public purposes, considered by the President and the Congress to be of sufficient national importance to warrant the expenditure of public funds. The management and control of such programs must be firmly in the hands of full-time Government officials clearly responsible to the President and the Congress. With programs of the size and complexity now common, this requires that the Government have on its staff exceptionally strong and able executives, scientists, and engineers, fully qualified to weigh the views and advice of technical specialists, to make policy decisions concerning the types of work to be undertaken, when, by whom, and at what cost, to supervise the execution of work undertaken, and to cvaluate the results.

"At the present time we consider that one of the most serious obstacles to the recruitment and retention of first-class scientists, administrators, and engineers in the Government service is the scrious disparity between governmental and private compensation for comparable work. We cannot stress too strongly the importance of rectifying this situation, through Congressional enactment of civilian pay reform legislation as you have recommended.

"3. Given proper arrangements to maintain management control in the hands of Governiment officials, Federally financed research and development work can be accomplished through several different means: Direct governmental operations of laboratories and other installations; operation of Government-owned facilities by contractors; grants and contracts with universities, contracts with not-for-profit corporations or with profit corporations. Choices among these means should be made on the basis of relative efficiency and effectiveness in accomplishing the desired work, with due regard to the riced to maintain and enlarge the long-term strength of the Nation's scientific resources, both public and private."

${ }^{3}$ Some of the problems, philosophy, and techniques of "contracting out" have been discussed in $3 \mathrm{I}$ Geo. WASh. L. REv. $685-783$ (1963).

$\$ 62$ Stat. 21 (1948), as amended, ro U.S.C. \$230r et seq. (1958). 
hend the necessity for any limitation upon his search for basic knowledge. The government lawyer, as a consequence, faced with an array of statutes, administrative procedures and requirements, legal precedents, and constitutional questions, has come to play an important part in the research program of the government, since contract administration, with the strict application of procedural and legal requirements necessarily imposed in view of the hige sums of money appropriated for defense spending, is as applicable to a basic research contract as to the purchase of a supply item. Yet, the unfettered search for scientific truth in broad areas of inquiry "limited only by the curiosity and creativity of the scientific investigator" would seem to require a different pattern than the confining limitations of a government contract administered under the Armed Services Procurement Act and Regulation. The contract format requires a rigid adherence to detailed, fixed rules, and must be complied with, even by the lawyer who recognizes that the initiative and creativity of the scientist cannot be unnecessarily curtailed if a research program is to be of any value and achieve maximum results. The mandatory utilization of prescribed clauses in government contracts which are not specifically geared to basic research sometimes taxes the ingenuity of the lawyer who has to explain what appear to the scientist to be unnecessary legalisms. Basic research for the military is no different than basic research for any other area of society. It requires highly trained technicians, complicated apparatus, education, imagination, and a detailed, comprehensive knowledge of the particular scientific area involved in the particular research being conducted. Consequently, to the university administrator, as well as to the Principal Investigator, it appears to be the epitome of "bureaucratize" to provide in the basic research contract that convict labor will not be utilized in the performance of the contract. Additionally, such clauses as "Standards of Work," where one of the major factors considered prior to awarding a contract is the professional reputation of the person who is to serve as the principal investigator; "Walsh-Healey Public Contracts Act" which applies to supply contracts for the manufacture or furnishing of materials, supplies, articles or equipment, and "Renegotiation" even though the Renegotiation Board Regulations exempt research contracts with educational institutions bearing no fee, would seem to have no place in a basic research contract. ${ }^{\mathbf{B}}$

\footnotetext{
${ }^{5}$ Senate Comm. on Government Operations, S. ReP. No. 2044, 85th Cong., 2d Sess. (I958); see also Research and Developaient Procurement Law (Federal Bar Journal, Vol. 17, Nos. 3 and 4, I957), which is a collection of articles on problems involved in procurement of research.

o The following clauses are required by the Armed Services Procurement Regulations in Basic Research contracts with educational institutions: ASPR 7-402.I, Definitions; 7-402.2, Limitation of Cost; 7-402.3, Allowable Cost, Fixed Fee, and Payment; 7-402.4, Standards of Work; 7-402.5, Inspection and Correction of Defects; 7-402.6, Assignment of Claims; 7-402.7, Examination of Records; 7-402.8, Subcontracts; 7-402.9, Utilization of Small Business Concerns; 7-402.I0, Termination; 7-402.II, Disputes; 7-402.12, Renegotiation; 7-402.13, Buy American Act; 7-402.14, Convict Labor; 7-402.15, Walsh-Healey Public Contracts Act; 7-402.I6, Work Hours Act of 1962 -Overtime Compensation; 7-402.17, Nondiscrimination in Employment; 7-402.18, Officials Not to Benefit; 7-402.19, Covenant Against Contingent Fees; 7-402.20, Authorization and Consent; 7-402.2I, Notice and Assistance Regarding Patent Infringement; 7-402.22, Patent Rights; 7-402.23, Basic Data Clause; 7-402.24, Military Security Requirements; 7-402.25, Government Property; 7-402.26, Insurance-Liability to Third Persons; 7-402.27, Utilization of Concerns in
} 
Outside of defense-related research, there was a parallel development in the manner research was let. This was the system whereby money was given outright through a grant. There was really nothing new in the use of government grants for research and development purposes; the practice, however, had been haphazard and had not been formalized to any significant degree until the I940's and I950's. For example, as early as 1842 , Samuel F. B. Morse received a subsidy of $\$ 30,000$ from the federal government to continue his work on the telegraph. A few years later, using the subsidy to Morse as a precedent, Congress granted $\$ 20,000$ to one Charles G. Page, an examiner at the U.S. Patent Office, to develop an electric motor. A formal grant program was begun only in 1887 , when the Department of Agriculture was empowered to make grants to the various state agricultural experiment stations. Not until 1944, under the Public Health Service Act of that year, was another government agency, the National Institute of Health (NIH), given specific grant authority. But, unlike Department of Agriculture grants, the bulk of NIH grants would not go to public institutions but to private medical schools and hospitals. Then, in 1950, with the founding of the National Science Foundation (NSF), came what was perhaps the clearest enunciation of federal support of scientific research grants. Here was a commitment by the federal government to support basic research as an integral part of national policy.?

Labor Surplus Areas; 7-402.28, Payment for Overtime and Shift Premiums; 7-402.29, Compctition in Subcontracting; 7-402.30, Audit and Records; 7-402.31, Price Reduction for Defective Cost or Pricing Data; 7-402.32, Subcontractor Cost and Pricing Data.

The following clauses are to be used when applicable: ASPR 7-403.I, Clauses for Contracts Involving Construction Work; 7-403.2, Filing of Patent Applications; 7-403.3, Reporting of Royalties; 7-403.4, Excess Profit; 7-403.5, Excusable Delays; 7-403.6, Preference for Certain Domestic Commodities; 7-403.7, Priorities, Allocations, and Allotments; 7-403.8, Soviet-Controlled Areas; 7-403.9, Negotiated Overhead Rates; 7-403.Io, Notice to the Government of Labor Disputes; 7-403.II, Gratuities; 7-403.12, Limitation on Withholding of Payments; 7-403.I3, Small Business Subcontracting Program; 7-403.14, Changes to Make or Buy Program; 7-403.15, Quality Control System; 7-403.16, Flight Risks; 7-403.17, Duty-Free Entry; 7-403.18, Duty-Free Entry of Listed Canadian Supplies; 7-403.19, Taxcs; 7-403.20, Advance Payments; 7-403.21, Workmen's Compensation Insurance Overseas; 7-403.22, Required Source for Jewel Bearings; 7-403.23, General Services Administration Supply Sources; 7-403.24, Labor Surplus Area Subcontracting Program; 7-403.25, Interest; 7-403.26, United States Products (Military Assistance Program); 7-403.27, Value Engineering Program Requirement; 7-403.29, Value Enginecring Program Requirement with Incentive.

The following clauses are considered "Additional Clauses" and may be used when applicable: ASPR 7-404.x, Changes; 7-404.2, Alterations in Contract; 7-404.3, Approval of Contract; 7-404.4, Bill of Materials; 7-404.5, Stop Work Orders; 7-404.6, Reports of Work; 7-404.7, Taxes Where Foreign Agreements Do Not Apply.

In addition to the above ASPR clauses the following clauses are required by the Air Force Procturement Instructions when certain conditions exist: AFPI 7-403.5I, Financial Management Report when the contract is in excess of \$roo,000 with nonprofit institutions; AFPI 7-4012, Rental of Gas Cylinders, when' the contract provides for the rental of gas cylinders; AFPI 7-4052, Use of Government Facilities on NoCharge Basis, where facilities have been placed with a prime contractor under a facilitics contract and it is desired to permit the use of such facilities on a no-charge basis; 7-4053, Notice of Radioactive Materials, when it is known that items will contain radioactive materials or which will become radioactive as a result of work accomplished under the contract; 7-4054, Limitation of Government's Obligation, to be used when total funds estimated to finance the contract are not available and it may be necessary to contract for the requirement notwithstanding the nonavailability of total funds and it can be reasonably anticipated that more funds will be made available for future funding of the contract involved; and 7-4066, Restrictions on Printing, when the contract requires the reproduction of rcports, data, or other written material.

${ }^{7}$ A. Hunter Dupree, Science in the Federal Governarent 370-73 (I957); Bledsoe \& Ravitz, 
These two parallel developments in the manner of letting research seemed to infer a distinction between research conducted for peaceful purposes and research conducted for defense. Defense-related research was presumably geared to more or less specific problems and required the close monitoring made possible by the contract; research sponsored by a federal grant was presumably more general in nature and was conducted for its own sake. In the final analysis, however, as the Armed Services increasingly recognized a need to sponsor basic research in selected scientific areas as well as applied research, the distinction would appear to be somewhat synthetic. Although different agencies had different research interests, defense-related research procured by contract is concerned with investigations of a very fundamental nature. And, in any basic research program, the scientific investigator is to some extent in the driver's seat, more or less free to take his investigation wherever it leads him. ${ }^{8}$

Once it became clear that this distinction was rather artificial, it also became evident that grant authority should be extended to all agencies engaged in extramural basic research. The overriding reason for such a reform was that the contract, in its existing form, was clearly not well suited as an instrument for conducting basic research. ${ }^{9}$

Over the years, the various agencies contracting for research had been largely unsuccessful in modifying the existing procurement regulations so as to give the research contract an appreciably simpler content than the ordinary procurement contract. Moreover, since research procurement really made up a very small portion of the total procurement activities of government, procurement administrators, naturally, spent most of their time and thought on problems connected with development and "hardware" contracts. As a result, many of the contractual elements that were germane to industrial procurement, but alien to research, were retained in the research contract. The investigator, in particular, felt that he was needlessly encumbered with red tape and with financial or other reporting requirements that imposed a cold, detail-watching attitude inappropriate to the research situation.

Actually, not all the things that universities and investigators complained about were intrinsic features of a contract per se. For example, technical (as distinct from financial) reporting requirements could be put in or taken out more or less at the discretion of the contracting agency. Nor is it beyond the bounds of possibility to devise a considerably more simplified form of contract expressly designed for the procurement of basic research. ${ }^{10}$

The Evolution of Research and Development as a Procurement Function of the Federal Government, I7 FED. B.J. I 89 (1957); Glockler, The Contractual Versus the Grant Approach to Basic Research Activities, id. at 265,274 .

${ }^{8}$ As late as 1955 Vannevar Bush was still making a distinction between research conducted for military purposes and that conducted purely out of intellectual curiosity. Bush, For Man to Know, Atlantic Monthly, August, 1955, pp. 29-34.

${ }^{\circ}$ The author is indebted to the Office of Information Services, Historical Division, Hq., Office of Acrospace Research, for background material used in discussion of Pub. L. No. 85-934.

${ }^{10}$ Harold Ordans, The Effects of Federal Prograns on Higher Education 3 I4 (I962); 
The grant was a somewhat different instrument, especially as its use evolved under the National Science Foundation. Simple in content, easy to manage, and free of all "boiler-plate," it avoided most of the detailed administration contained in the government contract. It readily allowed payment to be made in advance, thus putting fewer demands on a university's supply of working capital. On the other hand, advance payments under a contract required specific arrangements that were easy for some, but by no means easy for all colleges and universities to make. Then, too, with a grant, financial reporting is at a minimum and the burden of administration for the grantor agency, the grantee, and the investigator is less burdensome. ${ }^{11}$

It was not until 1958 that it was proposed to Congress there was a need for legislation which would extend grant authority to all federal research agencies. Dr. Allen T. Waterman, Director of the National Science Foundation, was the prime congressional witness at the hearings conducted in conjunction with the Science and Technology Act of $1958 .{ }^{12}$ In submitting its request for new legislation, the National Science Foundation defined Basic Research as that type of research which is directed towards increase of knowledge in science where the primary aim of the investigator is a fuller knowledge or understanding of the subject under study, rather than a practical application thereof. The National Science Foundation outlined the advantages of the grant over the contract: ${ }^{13}$

Where the Government desires to engage the services of an educational or nonprofit organization for the conduct of a specific piece of research directed toward a specific problem, the use of the contract form is obviously in order. On the other hand, where it is the desire of the Government to stimulate and support fundamental research in a given field, with the perimeters of inquiry limited only by the curiosity and creativity of the scientific investigator, the use of the grant form has several marked advantages.

First, the psychological relationship between the recipient institution or individual and the Government is more in keeping with the concept of maximum freedom of action for the scientific investigator. Second, the problem is avoided of endeavoring to adapt detailed contract regulations designed primarily for the procurement of hardware to the support of creative, fundamental research. Third, advance payment of the grant can be made without the vouchering of expenditures and accompanying "progress reports" or

vom Baur, Government Contracts: Small Business and the Law, 43 A.B.A.J. 605 (x957); Bledsoe \& Ravitz, stupra note 7, at 208-09; Letter From Roswell L. Gilpatric, Deputy Secretary of Defense, to Senator A. Willis Robertson, May I, 1962, in Hearings Before the Stubcomm. of the Scnatc Comm. on Appropriations, on H.R. 11289, DOD Appropriations for 1963, 87th Cong., 2d Sess. 1339-40 (1963); Whelan, Public Law 85-934: New Federal Support for Basic Scientific Research, 8 J. Pun. L. 462 (1959); Hearings Before the Subcomm. of the House Comm. on Appropriations on Department of Defense Appropriations, 1963, 87th Cong., 2d Sess. Pt. 5, at 143 (1963).

${ }^{12}$ OrLans, op. cit. stupra note 10, at 313-15; Glockler, stupra note 7, at 265, 273. Aviation Weck, Sept. 25, 196x, p. 19. The United States Supreme Court, in deciding a case involving personalty grants, stated: "A word of broader significance than 'grant' could not have been used. Like its synonyms 'give' and 'bestow' it expresses a concession, the conferring of something by one person upon another." Nicholas \& Co. v. United States, 249 U.S. 34, 39 (1919).

${ }^{12}$ Hearings Before the Subcomm. of the Senate Comm. on Government Operations, on S. 4039, Science and Technology Act of 1958, 85th Cong., 2d Sess. Pt. 2, at 309 (1958).

${ }^{13}$ Id. at $30 \mathrm{r}$. 
other "proof of work"-both of which exercise a deadening effect upon the initiative of the scientist.

The accompanying bill is designed to enable agencies not now having such authority to exercise discretion as to the legal instrument to be used in the support of basic research at educational institutions and other non-profit organizations. The authority requested would be permissive, not mandatory, in character. If a particular undertaking were relatively narrow in scope, or if the agency for any reason desired to maintain a fairly close rein on the pursuit of the research, it could use the contract form. Conversely, if it were the agencies' desire in other cases to support fundamental research in a broad field, with full latitude for the choice of particular lines of inquiry, the grant instrument could be used.

A provision was further submitted which would authorize federal agencies supporting or contracting for research and development work at educational or nonprofit institutions to provide in the grants or contracts that title to equipment financed by the agency in connection with the research would rest with the institution without further obligation to the government, or on such other terms and conditions as the agency deemed appropriate.

The Senate report on the proposed bill, ${ }^{14}$ in approving the legislation, stated that in the considered judgment of the committee the bill was a meritorious measure which would promote the progress of scientific research in the United States by providing greater flexibility and economy in the conduct and administration of such research without authorizing any new projects or activities and without increasing federal expenditures. Very shortly thereafter Congress enacted Public Law $85-934^{15}$

It will be noted that the act is liberal in conception and is permissive and flexible rather than mandatory and rigid and sets down no guidelines for the administering agencies to follow. Although the new grant law was exempted from the provisions

${ }^{14}$ Senate Comm. on Government Operations, S. REP. No. 2044, 85th Cong., 2d Sess. (1958).

${ }^{10} 72$ Stat. I793 (1958), 42 U.S.C.A. $\$ \$ 1891-93$ (Supp. 1963):

"To authorize the expenditure of funds through grants for support of scientific research, and for other purposes.

"Be it enacted by the Senate and House of Representatives of the United States of America in Congress assembled, That the head of each agency of the Federal Government, authorized to enter into contracts for basic scientific research at nonprofit institutions of higher education, or at nonprofit organizations whose primary purpose is the conduct of scientific research, is hereby authorized, where it is deemed to be in furtherance of the objectives of the agency, to make grants to such institutions or organizations for the support of such basic scientific research.

"Sec. 2. Authority to make grants or contracts for the conduct of basic or applied scientific research at nonprofit institutions of higher education, or at nonprofit organizations whose primary purpose is the conduct of scientific research, shall include discretionary authority, where it is deemed to be in furtherance of the objectives of the agency, to vest in such institutions or organizations, without further obligation to the Government, or on such other terms and conditions as the agency deems appropriate, title to equipment purchased with such grant or contract funds.

"Sec. 3. Each agency or department of the Federal Government exercising authority granted by this Act shall make an annual report on or before June 3 th of each year to the appropriate committees of both Houses of Congress. Such report shall set forth therein, for the preceding year, the number of grants made pursuant to the authority provided in the first section of this Act, the dollar amount of such grants, and the institutions in which title to equipment was vested pursuant to section 2 of this Act.

"Approved September 6, 1958." 
of the Armed Services Procurement Regulation it was obvious that some guidelines and philosophy as to the administration of a grant would have to be formulated, which was accomplished shortly after the enactment of the statute. The administrative directives would appear to make it markedly clear that a grant for basic research is not a giveaway or a "Grant-in-Aid" to a university or nonprofit institution. ${ }^{10}$ It is a written agreement between the agency of Defense and the grantee which provides for a quid pro quo and although the many restrictions contained in government contracts are not present a grant agreement must contain certain prescribed conditions. ${ }^{17}$ Nevertheless, the grant instrument provides an administrative freedom and flexibility which is not present in the usual government contract. The mandatory clauses of the Armed Services Procurement Regulation are not incorporated; payments are made in advance; there are a minimum of conditions and requirements placed upon the grantee and the many details of the administration of government contracts are not present.

The flexibility of the grant instrument is such that despite the limitations and conditions imposed upon a grantee it has created a philosophy, in some quarters, that the grant is in fact a "Grant-in-Aid." This was particularly true immediately subsequent to the enactment of the statute and the implementing directives since there was no indication in the statute that the grantee would not receive the same overhead rate applicable to a government contract, but would be allowed full overhead based upon the particular accounting methods of the institution concerned.

No issue involving grants has been the subject of more heated discussion than the question of indirect or overhead costs. Obviously, the costs of a particular basic research investigation carried on at a university campus involve many fine distinctions since laboratory space, library facilities, light, heat, administrative and housekeeping services are all shared with university activities as well as privatelysupported research. These costs vary with each institution and it was necessary to establish a common base which would negate, to a great extent, the belief that all grantees were not on an equal basis. Despite the protestations of both universities and government officials, the problem of indirect costs was solved for the administrators of the grant program by the provision in the 1963 Department of Defense Appropriation Act which provided that none of the funds provided by such act could be used to pay any recipient of a grant for the conduct of a research project

\footnotetext{
${ }^{26}$ DOD Directive 3210.2, "Policy on Research Grants and Title to Equipment Purchased Under Grants," November 19, 1962, and DOD Instruction 3210.3, "Administration of Basic Rescarch Grants," August 25, 1959.

${ }^{17}$ Section VII, DOD Directive 3210.2, November 19, 1962, sets forth the following prescribed conditions that a grant instrument must contain. "Section VII. GRANT AGREEMENTS. The grant agrecment shall be brief in format, containing only those provisions which are required by specific statutes or for the protection of the fundamental interests of the Government. This includes matters such as the limitation of indirect costs to, at most, $20 \%$ of the total direct costs; the maintenance of records sufficicnt to cnable a determination that grant funds were expended for the purposes of the grant; the acquisition for the Government, in accordance with the patent and data policies of the Department of Defense set forth in Section IX of the Armed Services Procurement Regulation, appropriate rights to inventions and data arising out of the research; and provisions for the revocation of the grant."
} 
an amount for indirect expenses in connection with such project in excess of twenty per cent of the direct costs. In actual practice it is permissible for a grantee to receive as overhead an amount which shall exceed in equivalence neither twenty per cent of the total direct costs nor the indirect cost rate that has been most recently determined under applicable procedures at the grantee institution for comparable research contracts of the Department of Defense. ${ }^{18}$

The limitation on indirect costs which was imposed by Congress has been used as the basis for the argument that universities are in fact subsidizing government research. Since the grant is predicated upon the actual cost of the research, the proponents of this belief contend that by limiting overhead a cost of research is borne by the institution. The fact that the institution, as well as the government, is deriving significant benefits from the research is apparently overlooked. Research facilities have been made available to the universities; the highest calibre of scientific minds have a readily available forum for their research and are attracted to the universities; government-sponsored research has enabled the universities to have a program for the training of young scientists in all areas of scientific interest; the authority to vest title in equipment purchased with grant funds has enabled the universities to acquire facilities which otherwise would have to be paid from university funds. In short, the withdrawal of federal funds would undoubtedly be disastrous to the research program of many universities. In view of the limitation on indirect costs contained in the Appropriation Act, the "subsidization" theory is somewhat academic. Congress held lengthy hearings on this matter, heard all the arguments in favor of universities receiving full indirect costs in grants and apparently believed that defense-related research would not be hindered by an "across the board" limitation on overhead. In any event, this limitation, right or wrong, does not change the character of the grant from the concept of quid pro quo to a donation or gift. ${ }^{19}$

${ }^{18}$ ASPR 3-70r et seq., "3-70r.I NEGOTIATED FINAL OVERHEAD RATES. The term 'negotiated final overhead rate,' as used in this part means a percentage or dollar factor which expresses the ratio(s) mutually agreed upon by the Government and the contractor, at the close of a regularly stated period (preferably the contractor's fiscal year), of indirect expenses incurred in the period to direct labor, manufacturing cost, cost of sales, or other appropriate base of the same period. . . . In certain circumstances involving educational institutions, negotiated final overhead rates may be used as a means of determining the amount of reimbursement for the applicable indirect costs to be incurred during a future period of contract performance . . ; 3-702 PURPOSE. The major purposes of negotiated final overhead rates are: (i) to effect uniformity of approach in cases where more than one contract or more than one Military Department is involved; (ii) to effect economy in administrative effort; and (iii) to promote timely settlement of reimbursement claims."

${ }^{10}$ It is interesting to note that Dr. Henry Smyth, Chairman, University Research Board, Princeton University, in his testimony before the Senate Committee on Appropriations, in opposition to any legislation limiting overhead rates in grants for basic research stated as follows:

"The word 'grant' used to be an attractive one to university people. It carried the implication of a free gift with no strings of any kind attached. This is always the kind of money that universities like to receive. Unfortunately, from our point of view, a research grant from a Government agency to a university is by no means a free gift. Nor do I suggest that it should be so. In the field about which we are talking, that is to say, support of research by the Department of Defense, such research grants are arrangements between the Department of Defense and the university concerned to get research done which the Department of Defense believes is important for the strength of the country. It is very 
The primary difficulty engendered by the utilization of a grant instrument to provide for defense-related basic research is not the flexibility necessary to accomplish the desired result but a lack of appreciation of the basic philosophy underlying its purpose. The belief that a grant for a basic research project is in the form of a "Grant-in-Aid," is generated in part by the wide latitude afforded the grantee in the conduct of the research, the lack of the many administrative controls contained in the government contract, and perhaps even by the language of the statute itself which authorizes "grants . . . for the support of . . . basic scientific research." In differentiating between a government contract and a grant as an instrument to obtain basic research, Congress intended for governmental agencies engaged in basic research to procure this research by means other than current government contract procedures. ${ }^{20}$ It permitted the agencies themselves to formulate procedures to obtain this research, but by no stretch of the imagination could it be interpreted that it authorized governmental agencies to make donations or gifts to institutions engaged in scientific endeavors. ${ }^{21}$ Consequently, it is incumbent upon each agency to formulate rules and procedures which incorporate the concept of quid pro quo, and which establish beyond peradventure of doubt that the government is procuring research for the public interest. The common misconception that the grant to obtain government research is a donation or, at the least, a Grant-in-Aid, caused in part by its

properly expected that the university receiving such a grant shall use the money to advance knowledge in some particular field. The Department of Defense expects results and the university is under obligation to produce such results. ..."Hearings Before the Subcomm. of the Senate Comm. on Appropriations, on H.R. 11289, DOD Appropriations for 1963,87 th Cong., 2d Sess. 1703 (1963).

It is also noteworthy that Dr. Raymond J. Woodrow, Director of Office of Research Administration and Assistant Secretary of Princeton University, submitted a statement to the Senate Committec on Appropriations in opposition to any legislation limiting overhead rate in grants for basic research, as follows:

"Any of the present Government arrangements for financing research at colleges and universitics, whether they are called grants or contracts, are in the true legal sense contracts. A university is as bound by the terms and conditions of a research grant which it accepts, as by any contract. It cannot spend the funds for research outside the field specified by the grant, or for purposes other than rescarch, or for research under another principal investigator than the one named in the grant. . ." Id. at 1709.

${ }^{20}$ It is true that the negotiation involved in a government contract for basic research has been relieved to a great extent by the utilization of basic agreements which are incorporated in the contract. The Armed Services Procurement Regulation defines a basic agreement as follows: ASPR 3-410.1 "DESCRIP. TION. By definition a basic agreement is a written instrument of understanding executed between a Department or procuring activity and a contractor which sets forth the negotiated contract clauses which shall be applicable to future procurements entered into between the parties during the term of the basic agreement. The use of the basic agreement contemplates the coverage of a particular procurcment by the execution of a formal contractual document which will provide for the scope of the work price, delivery, and additional matters peculiar to the requirements of the specific procurement involved, and shall incorporate by reference or append the contract clauses agreed upon in the basic agreement as required or applicable."

${ }^{21}$ Dr. C. W. Schilling, Deputy Director, Division of Biology and Medicine, Atomic Energy Commission, in supporting testimony before the Senate, stated, in part: ". . . a grant in our mind is not intended as an outright gift to the research institution." Senate Comm. on Government Operations, S. REP. No. 2044, 85th Cong., 2d Sess. 7 (1958).

In this regard, Major Genieral Don R. Ostrander, Commander, Office of Aerospace Research, in an address to the American Rocket Society, National Capitol Section, said in part that "Nothing could be further from the truth than the accusation that the grant program is a 'giveaway' program. 'The grant is a legal instrument which can be made as flexible or restrictive as the parties thereto desire. ..." 
unfortunate appellation, can be eradicated in the first instance by administratively re-naming the instrument utilized to obtain basic research under Public Law No. 85-934 a "Research Agreement." The primary objective of the statute, namely, to provide greater flexibility and economy in the conduct and administration of scientific research, can be met by incorporating into the Research Agreement provisions which leave no question as to the flexibility and freedom of action granted to the scientific investigator. There should be a minimum of administrative controls similar to those contained in the present grant instrument, yet at the same time the instrument should leave no doubt that it incorporates the concept of procurement of basic research for a stated consideration.

The utilization of a legal instrument which provides for the utmost flexibility in scientific endeavors and contains a minimum of administrative controls but which also leaves no doubt that the money furnished for the research is not a gift, will have no deleterious effect upon the government's expressed intention to support fundamental research at universities or nonprofit institutions. If the means used to obtain the desired research does not restrict, confine, or limit the scientist or administrator engaged in the research inquiry, but at the same time gives full and adequate protection to the public interest, there will be complete compliance with the intent of Congress.

In view of the necessity for safeguarding governmental interests, which is a true function of the lawyer, it is sometimes difficult for the scientist who is engaged in basic research, where the primary aim is a fuller knowledge or understanding of the subject under study rather than a practical application thereof, to understand the role of the lawyer in his affairs. The lawyer who is supervising the legal aspects of basic research in government is immediately faced with the statutory prohibition that, except as otherwise provided by law, sums appropriated for the various branches of expenditure in the public service shall be applied solely to the object for which they are respectively made and for no others. ${ }^{22}$ Congress annually appropriates monies for research, development, testing and evaluation of which the basic research program is a part. It logically follows that a lawyer must have a complete understanding of the purpose of a contract or grant under review for the initial purpose of determining whether the expressed purpose of the contract or grant falls within the purview of the appropriation. In other words, a determination must be made as to whether the monies to be expended are in fact for basic research. Since it is an obvious conclusion that a scientist is in a much better position to determine whether a particular scientific project falls within the purview of basic research, there has been a feeling that the scientist must, in the final resort, have the last word. Nevertheless, the scientific community must realize that the lawyer has an obligation to insure that the purposes of the contract or grant fall within the purview of the particular appropriation involved. Generally speaking, this is not an insurmountable problem once the scientist is convinced that the lawyer is desirous

\footnotetext{
${ }^{22}$ REv. STAT. $\$ 3678$ ( 1875 ), 3I U.S.C. $\$ 628$ (I958).
} 
of helping rather than hindering the search for knowledge in all scientific areas. This understanding can be realized once the philosophy of the contract or grant in the governmental research program is comprehended. If, as some scientists would like to believe, the government research program is primarily geared to the support of science and the support of universities engaged in basic research programs, obviously any program which falls within the general confines of this concept would be permissible. If, on the other hand, the concept is uppermost that appropriated monies for research must in fact be expended solely for research, then there is bound to be a clash between the scientist who does not adopt this philosophy and the lawyer who is attempting to safeguard governmental funds by insuring that appropriated monies are expended for the purposes intended. For example, it may be contended that a research contract or grant which supplies money to a university solely for the construction of a laboratory is in fact a research project since a laboratory is essential for the proper performance of any scientific program. Whether such a project can be considered research, in view of the appropriation statutes, may, of course, be another question, and it is the function of a lawyer to convince the scientist that the expenditure of government funds must be within the purview of the appropriation statutes. One basis for the misconception on the part of some scientists is the failure to realize that the statute authorizing the utilization of a grant instrument is not a statute authorizing expenditure of public funds. There is not ingrained as yet in the minds of some government scientists, whether they be administrators or bench scientists, that the grant instrument is merely a means of obtaining a desired result with the minimum of restrictions and the utmost flexibility. For this reason, if for no other, there is a need for an instrument, contractual in nature, which does not contain the same clauses required in the present government contract yet makes it crystal clear that a grant is not a gift to the grantee. Illustrative of the misconception as to the nature of the grant, it is not uncommon for the research assistant who is employed by a grantee university as a graduate student to assist the principal investigator in his scientific endeavors, to believe that the salary he receives from the university for his activities on behalf of the research is tax exempt as a "Grant-in-Aid" from the government to further his education. Even some university administrators fail to understand that the money received from the government under the grant instrument, part of which is used to pay the salary of a graduate research assistant, is not a gratuitous contribution from the government directly to the research assistant.

It is one of the functions of the lawyer who is functioning in the scientific community to help develop the basic philosophy that the university engaged in basic research is supporting the government in its search for knowledge along certain defined areas and that, although the government is supporting research in the university by its basic research program, it is not its function to support the institution by means of donations for scientific purposes.

Government interests in science cover the entire spectrum of scientific endeavor 
and, as mentioned heretofore, necessarily require the assistance of the top scientific minds in the United States. As a direct result of this need and the obvious inability of the government to furnish the essential scientific talent through its own resources, it was recognized that talent outside of government circles was required to help guide programs in each scientific area which was of interest to the government. Although basic research is a search for pure knowledge, there must be a raison d'etre for research; policies must be formulated to guide the direction of the research; guidance is necessary and essential to assist the government in its determination as to which areas must be emphasized, which pursuits are of utmost urgency, which areas of science require emphasis, and to obtain advice, views, and recommendations with respect to the scientific programs of the government. This dependence upon individuals not connected with government who will be concerned with governmental programs has generated certain problem areas. In a memorandum of May 2, 1963 to the heads of the executive departments and agencies, the President emphasized this need and consequent problem area. ${ }^{23}$

The President's memorandum was issued subsequent to the enactment by Congress of Public Law $87-849^{24}$ which revised the conflicts of interests laws as unduly restrictive in application to temporary and intermittent employees. As the President pointed out, Congress dealt with these difficulties by establishing a category known as "Special Government Employees" and made the restrictions imposed upon their private activities less extensive than those applied to regular employees. In view of these restrictions, limited though they may be, the lawyer in the scientific community has an active interest to insure that the advisers and consultants are properly informed of the rules and regulations applicable to them as advisers or consultants, and that their status as special government employees does not come into conflict with their private interests. The President recognized this in his memorandum and required a legal review of each statement of private employment and financial interests for a determination as to possible conflicts of interest.

The conflicts of interests statute, of course, has many ramifications affecting "special government employees" as well as full-time and former government em-

23 "Over the past twenty or more years departments and agencies of the Government have made increasing use of temporary or intermittent consultants and advisers who serve individually or on advisory bodies. The employment of highly skilled persons on a temporary or intermittent basis is in the interest of the Government and provides it with an indispensable source of expert advice and knowledge. However, since such persons have their principal employment outside the Government, conflict of interest problems arise from time to time.

"More particularly, many persons serving the Government temporarily or intermittently are individuals with specialized scientific knowledge and skills whose regular work is in industry, research institutes or educational institutions. An individual employed by a university may act as an intermittent consultant not only for the Government but for a private firm and either his university or the firm or both may be engaged in work for or supported by the Government. A Consultant to the Government may have other financial connections with firms doing business with the Government in the general area of his expertise and, therefore, his consultancy. The many possible interrelationships between a consultant's service to the Government and his own and his employer's or client's financial interests demonstrate that conflict problems may often arise."

${ }^{24} 76$ Stat. III9, 18 U.S.C. \$ 201 (Supp. IV, 1962). 
ployees, and a lawyer, necessarily, has a vital part to play in safeguarding the public interest. ${ }^{25}$ He must utilize not only his legal knowledge in the interpretations of the laws and directives in its application to a particular case in hand, but must exercise the utmost tact and diplomacy in his contact with the specialist who is offering his services to aid the government in its scientific programs. It requires not only tact and diplomacy but a knowledge of business affairs, a high sense of moral and ethical conduct, and an understanding that public service requires ethical behavior of the highest order.

The role of the lawyer in the scientific community encompasses considerably more than the important function in the review of contracts and grants for "legal sufficiency." A knowledge of government procurement is essential, of course, to insure the applicability of the procedural requirements in the procurement of basic research. Patent rights, ${ }^{26}$ utilization of data ${ }^{27}$ evolved from research, proper application of overhead ${ }^{28}$ as a cost to the government, fulfillment of statutory requirements under the Armed Services Procurement Act ${ }^{20}$ relative to manner of procurement, application of Buy American Act, ${ }^{30}$ determination of proper application of funds, ${ }^{31}$ disposition of government property, ${ }^{32}$ compliance with executive orders and requisite regulatory and statutory ${ }^{33}$ requirements, are but some of the areas examined by the lawyer in his review of contracts and grants, to insure the full protection of the public interest. ${ }^{34}$

It is the lawyer's objectivity and his ability to critically examine concepts and philosophies unhampered by a personal sense of involvement, however, which can be the basis for a vital and significant contribution to the scientific community in government. His appreciation of the scientific objectives and mission of his organization, tempered by an objectivity not necessarily possessed by the scientist or administrator deeply and personally involved in the race for scientific progress, can make the lawyer the unshakeable bridge between the scientific community and those administering a research program, to insure the accomplishment of the governmental scientific program is in the best public interest.

\footnotetext{
${ }^{25}$ See Petrowitz, Conflict of Interest in Federal Procurement, in Part I of this symposium, at 196 . 224; Perkins, The New Federal Conflict of Interest Law, 76 Hanv. L. REv. I113 (1963), for a comprchensive analysis of the new law; also, DOD Directive 5500.7, May 17, 1963; and AFR 30-30 which implements the statute and DOD Directive.

${ }^{20}$ ASPR 9-107 et seq., 32 C.F.R. $\$ 9.107$ et seq. (1963).

${ }^{27}$ ASPR 9-200 et seq., 32 C.F.R. $\$ 9.200$ et seq. (1963).

${ }^{28}$ ASPR 3-700 et seq., 32 C.F.R. $\$ 3.700$ et seq. (1963).

${ }^{29} 62$ Stat. 21 (1948), as amended, ro U.S.C. $\$ 230$ r et seq. (I958).

${ }^{30}$ ASPR 6-100 et seq., 32 C.F.R. $\$ 6.100$ et seq. (1963).

${ }^{81}$ REV. STAT. $\$ 3678$ (1875), 3I U.S.C. $\$ 628$ (1958).

${ }^{32}$ ASPR I3-100 et seq., ASPR Appendices $B$ and $C$.

${ }^{38}$ See Research and Development Contracting (Federal Publications, Inc. 1963), which discusses some of the legal and practical problems in research contracting.

${ }^{36}$ Contractual procedures for Basic Research currently utilized under the Armed Services Procurement Act are affected by the recent decision of the Court of Claims in G. L. Christian \& Associates v. United States, $3 \mathrm{I2}$ F.2d $4 \mathrm{18}$ ( $\mathrm{Ig}_{3}$ ), motion for rehearing and reargument denied, 320 F.2d 345 ( 1963 ), cert. denied, 375 U.S. 954 (I963), petition for rehearing denied, 376 U.S. 929 (1964).
} 